\title{
Micropruina glycogenica gen. nov., sp. nov., a new Gram-positive glycogen-accumulating bacterium isolated from activated sludge
}

\author{
Tomoyoshi Shintani, ${ }^{1,3}$ Wen-Tso Liu, ${ }^{2}$ Satoshi Hanada, ${ }^{3}$ \\ Yoichi Kamagata, ${ }^{3}$ Shunsuke Miyaoka, ${ }^{1}$ Takaaki Suzuki ${ }^{1}$ \\ and Kazunori Nakamura ${ }^{3}$
}
1 Industrial Research Center of Ehime Prefecture, Matsuyama, Ehime 791-1101, Japan
2 Institute of Life Sciences, National Central University, Chungli 32054, Taiwan, Republic of China
3 National Institute of Bioscience and Human- Technology, Agency of Industrial Science and Technology, 1-1 Higashi, Tsukuba, Ibaraki 305-8566, Japan

Author for correspondence: Kazunori Nakamura. Tel/Fax: +81298546054. e-mail:knakamur@nibh.go.jp

\begin{abstract}
A new Gram-positive non-spore-forming bacterium, strain $\operatorname{Lg}^{\top}{ }^{\top}$, was isolated from an activated sludge reactor showing enhanced biological phosphorus removal activity. The new isolate was a slowly growing organism and was capable of accumulating large amounts of intracellular glycogen from substrate taken up. Both oxidase and catalase were produced. The new isolate contained meso-diaminopimelic acid (DAP) in the cell wall. Complex fatty acid patterns with iso- $\mathrm{C}_{14: 0,}$ anteiso- $\mathrm{C}_{15: 0,}, \mathrm{C}_{16: 0,}$, iso- $\mathrm{C}_{16: 0}$ and four other minor saturated or unsaturated straight-chain fatty acids were detected. The isolate contained a high genomic G+C content $(70.5 \mathrm{~mol} \%)$. Phylogenetic analysis based on the 16S rRNA gene sequence placed the isolate in the high G+C Grampositive group with Microlunatus phosphovorus and Friedmanniella antarctica as the closest relatives (sequence similarities are 93 and $92 \%$, respectively). These three organisms shared common features in morphology, but strain Lg2 ${ }^{\top}$ could be differentiated from the other species by its peptidoglycan type (meso-DAP), fatty acid composition, carbon source utilization profile and G+C content. On the basis of these findings, it is proposed that a new genus and species, Micropruina glycogenica, should be created for the new isolate; the type strain is strain $\operatorname{Lg}^{\top}\left(=\right.$ JCM $\left.10248^{\top}\right)$.
\end{abstract}

Keywords: Micropruina glycogenica gen. nov., sp. nov., high $\mathrm{G}+\mathrm{C}$ content group, Gram-positive bacteria, glycogen accumulation

\section{INTRODUCTION}

Activated sludge processes employ concentrated mixed microbial biomass $\left(2-4 \mathrm{~g}^{-1}\right)$ to eliminate organic materials from industrial wastewater and sewage before disposal. Recently, application of these processes has been further expanded to remove inorganic nutrients from wastewater. One good example is the enhanced biological phosphorus removal (EBPR) process. EBPR is established by the dominant growth of polyphosphate-accumulating bacteria in the activated sludge process utilizing anaerobic conditions with substrate addition and subsequent aerobic conditions. However, the EBPR process is difficult to control, and

Abbreviations: DAP, diaminopimelic acid; EBPR, enhanced biological phosphorus removal.

The GenBank/EMBL/DDBJ accession number for the 16S rRNA gene sequence of strain $\mathrm{Lg}^{\top}$ is $\mathrm{AB} 012607$. sometimes fails in phosphorus removal performance. For stable operation, a better understanding of the micro-organisms in the activated sludge of the EBPR process is required. However, little is known about the microbiology of the EBPR process, and one of the reasons is the inability to isolate representative microorganisms.

Acinetobacter spp. are the most common isolates from this process (Fuhs \& Chen, 1975; Deinema et al., 1980; Cloete et al., 1985; Groenestijn et al., 1989; Streichen et al., 1990; Lötter \& Pitman, 1992; Beacham et al., 1992), but the community analyses using molecular techniques do not support their predominance in the EBPR process (Cloete \& Steyn, 1987; Wagner et al., 1993, 1994). Other known bacterial isolates include Pseudomonas sp. (Suresh et al., 1985), Arthrobacter globiformis (Shoda et al., 1980) and Lampropedia spp. (Stante et al., 1997). Nevertheless, these isolates could not store substrate (i.e. cellular 
glycogen and polyhydroxyalkanoate) and accumulate polyphosphate; although these abilities are observed in the EBPR process (Ohtake et al., 1985; Groenestijn et al., 1989). At present, only one bacterium, Microlunatus phosphovorus, isolated from the EBPR process has been demonstrated to accumulate intracellular polyphosphate and store substrate as a carbon reserve (Nakamura et al., 1991, 1995a, b). Many researchers have suggested that, in contrast to the pure cultures used in the aforementioned studies, the microbial community of the EBPR process is composed of diverse micro-organisms at different phylogenetic positions (Wagner et al., 1994; Bond et al., 1995). To solve this microbial ecology puzzle, we have focused on isolating and identifying representative bacteria from EBPR processes.

A new bacterium capable of accumulating intracellular glycogen was isolated from an EBPR process. The organism, designated $\mathrm{Lg} 2^{\mathrm{T}}$, was morphologically similar to Microlunatus phosphovorus, but exhibited no polyphosphate-accumulation ability. In this paper, we describe the phenotypic and phylogenetic characteristics of the new isolate, and propose to create a new genus and species name, Micropruina glycogenica, for the isolate.

\section{METHODS}

Bacterial strain and culture conditions. Strain $\operatorname{Lg} 2^{\mathrm{T}}$ was previously isolated from an anaerobic-aerobic sequential batch reactor exhibiting EBPR activity (Liu et al., 1997). A previously described NM-1 agar medium (Nakamura et al., $1995 \mathrm{~b})$ contained $\left(\mathrm{l}^{-1}\right) 0.5 \mathrm{~g}$ glucose, $0.5 \mathrm{~g}$ peptone, $0.5 \mathrm{~g}$ monosodium glutamate, $0.5 \mathrm{~g}$ yeast extract, $0.44 \mathrm{~g} \mathrm{KH}_{2} \mathrm{PO}_{4}$, $0 \cdot 1 \mathrm{~g}\left(\mathrm{NH}_{4}\right)_{2} \mathrm{SO}_{4}, 0 \cdot 1 \mathrm{~g} \mathrm{MgSO}_{4} \cdot 7 \mathrm{H}_{2} \mathrm{O}$ and $15 \mathrm{~g}$ agar (final $\mathrm{pH}$ was 7.0). Liquid cultures were established by using the same medium without agar, and the cultures were incubated at $30{ }^{\circ} \mathrm{C}$ with a gentle shaking. For estimation of the optimal temperature and $\mathrm{pH}$ range for growth, the isolate was aerobically cultured under the following conditions: $5,9,16$, $20,23,26,30,33,35,37$ and $40^{\circ} \mathrm{C}, \mathrm{pH} 4,5,6,7,8,9$ and 10 . The growth rate of the isolate was determined by measuring the $\mathrm{OD}_{600}$ with a spectrophotometer (Beckman DU 640).

Morphological characteristics. Gram and Neisser staining were performed as described by Magee et al. (1975) and Jenkins et al. (1993), respectively. Morphology was examined by phase-contrast microscopy and transmission electron microscopy. For transmission electron microscopy, a centrifuged cell pellet was fixed with $5 \%(\mathrm{v} / \mathrm{v})$ glutaraldehyde and $1 \%(\mathrm{v} / \mathrm{v})$ osmium tetroxide. Ultrathin sections of the sample embedded in epoxy resin (Kushida, 1980) were prepared with a Reichert ultramicrotome. Samples were stained with uranyl acetate and lead citrate, and examined using a Hitachi H-7000 transmission electron microscope.

Physiological and biochemical characterization. Oxidase activity was determined by monitoring the oxidation of tetramethyl-p-phenylenediamine on a filter paper (Smibert \& Krieg, 1981). Catalase activity was determined by adding cells to a $3 \%$ hydrogen peroxide solution (Smibert \& Krieg, 1981). For the determination of nitrate reduction, strain $\mathrm{Lg} 2^{\mathrm{T}}$ was grown in a medium containing $1.0 \mathrm{~g} \mathrm{NaNO}_{3} 1^{-1}$ under anaerobic conditions. The anaerobic conditions were established by replacing the gas phase in a butyl rubber stopper sealed test tube with $\mathrm{N}_{2}$. Denitrification was determined by detecting the production of nitrogen gas during anaerobic growth on nitrate. The organic substrate utilization activities under aerobic conditions were determined using the BIOLOG system.

Quinone, fatty acid and cell wall analyses. Quinones were extracted from freeze-dried cells with chloroform/methanol $(2: 1, v / v)$ and $n$-hexane. The extract was purified by SepPak Plus (Waters) and analysed by reverse-phase HPLC for identification (Tamaoka et al., 1983). Whole-cell fatty acids were converted to methyl esters by treatment with anhydrous methanolic $\mathrm{HCl}$. Methyl esters were extracted with n-hexane (Komagata \& Suzuki, 1987), and analysed by using a gas chromatograph equipped with a flame-ionization detector (model HP5890II; Hewlett Packard). GC-MS analysis was performed with a JEOL SX102A mass selective detector directly connected to a gas chromatograph. The presence of diaminopimelic acid (DAP) isomers in the cell wall peptidoglycan was determined by TLC (Merck; no. 5716) after hydrolysis with $6 \mathrm{M} \mathrm{HCl}$ at $100{ }^{\circ} \mathrm{C}$ for $18 \mathrm{~h}$ (Komagata \& Suzuki, 1987).

Glycogen accumulation measurement. Strain $\operatorname{Lg} 2^{\mathrm{T}}$ was cultured in a $500 \mathrm{ml}$ flask containing $200 \mathrm{ml} \mathrm{NM}-1$ medium up to $8 \mathrm{~d}$ under aerobic conditions at $30^{\circ} \mathrm{C}$. At a $1 \mathrm{~d}$ interval, cells were harvested, rinsed with $0.85 \% \mathrm{NaCl}(\mathrm{w} / \mathrm{v})$, and dried overnight. Before the determination of glycogen content, the dried cells $(100 \mathrm{mg})$ were washed with ethanol and hydrolysed using $4 \mathrm{M} \mathrm{HCl}$ for $6 \mathrm{~h}$ at $100{ }^{\circ} \mathrm{C}$ (Elson \& Morgan, 1993; Lott \& Turner, 1975). The glycogen content of cells was measured with a Glucose CII test kit (Wako Pure Chemical Industries) according to the manufacturer's protocol.

DNA base composition. Total DNA of strain $\mathrm{Lg} 2^{\mathrm{T}}$ was extracted according to the method described previously (Kamagata \& Mikami, 1991). The extracted total DNA was digested with P1 nuclease using a Yamasa GC kit (Yamasa Shoyu). The $\mathrm{G}+\mathrm{C}$ content of the total DNA was measured by HPLC (Shimadzu model LC-6A system) equipped with a CLC-ODS column (6 by $150 \mathrm{~mm}$; Shimadzu).

$16 \mathrm{~S}$ rRNA gene sequence and phylogenetic analysis. The $16 \mathrm{~S}$ rRNA gene (rDNA) fragment of strain $\mathrm{Lg} 2^{\mathrm{T}}$ was amplified by PCR (Hiraishi, 1992; Hiraishi et al., 1994) and sequenced directly with a dRhodamine dye terminator cycle sequencing kit (Applied Biosystems) and a model ABI 377 DNA sequencer. The $16 \mathrm{~S}$ rDNA sequence obtained and reference sequences were aligned by using the CLUSTAL W program, version 1.5 (Thompson et al., 1994). Phylogenetic trees were constructed from the evolutionary distance matrix calculated by the neighbour-joining method (Saitou \& Nei, 1987) with Kimura's two-parameter correction. The neighbour-joining analysis was performed with the MEGA program (Kumar et al., 1993). All gaps in the alignment were excluded; 970 bases were compared.

Nucleotide sequence accession numbers. The accession numbers of the reference sequences used in the phylogenetic analysis are as follows: Aeromicrobium erythreum, AF005021; Bacillus subtilis, X60646; Corynebacterium xerosis, X81914; Friedmanniella antarctica, Z78206; Luteococcus japonicus, D21245; Microlunatus phosphovorus, D26169; Nocardioides albus, X53211; Nocardioides jensenii, Z78210; Nocardioides plantarum, Z78211; Nocardioides simplex, Z78212; Propionibacterium freudenreichii, X53217; and Propionibacterium thoenii, X53220. The sequence of Propioniferax innocua was directly taken from the report by Pitcher \& Collins (1991). 


\section{RESULTS}

\section{Isolation and growth conditions}

Strain $\operatorname{Lg} 2^{\mathrm{T}}$ was previously isolated from a sequential batch reactor for EBPR (Liu et al., 1997), and was extensively characterized in this study. When grown on the NM-1 agar medium plate, the strain required 2-3 weeks to develop a white, punctate colony. Growth was very slow in the liquid medium under aerobic conditions. The doubling time was approximately $12 \cdot 6 \mathrm{~h}$ at $30{ }^{\circ} \mathrm{C}$. The temperature range for growth was $20-35^{\circ} \mathrm{C}$, and the optimal growth temperature was $30{ }^{\circ} \mathrm{C}$. Growth was not observed below $16^{\circ} \mathrm{C}$ or above $37^{\circ} \mathrm{C}$. The $\mathrm{pH}$ range for growth was between 6 and 8 with the optimum at $\mathrm{pH} 7 \cdot 0$. The strain could grow in the presence of $\mathrm{NaCl}$ up to $3 \cdot 0 \%(\mathrm{w} / \mathrm{v})$.

\section{Morphological characteristics}

Cells of strain $\mathrm{Lg} 2^{\mathrm{T}}$ were Gram-positive, non-motile cocci, occurring in pairs, packets or clusters. The size of each cell varied from 0.5 to $2.2 \mu \mathrm{m}$ in diameter (Fig. 1). No spore formation was observed. Electron microscopic observations of ultrathin sections (Fig. 2) showed that the individual cells of the strain were approximately $1 \mu \mathrm{m}$ wide. Cells possessed the typical cell wall structure of a Gram-positive bacterium. A septum was often observed in the middle of each growing cell. Capsules were present around the cells. No intracytoplasmic membrane was observed.

\section{Glycogen-accumulating activity}

Strain $\operatorname{Lg} 2^{\mathrm{T}}$ was able to take up and convert glucose into cellular carbohydrate (i.e. glycogen) under either aerobic or anaerobic conditions (Liu, 1995). Fig. 3 indicates the cellular glycogen profile of strain $\mathrm{Lg}^{\mathrm{T}}$ during cultivation in NM-1 medium under aerobic conditions. The cellular glycogen content increased

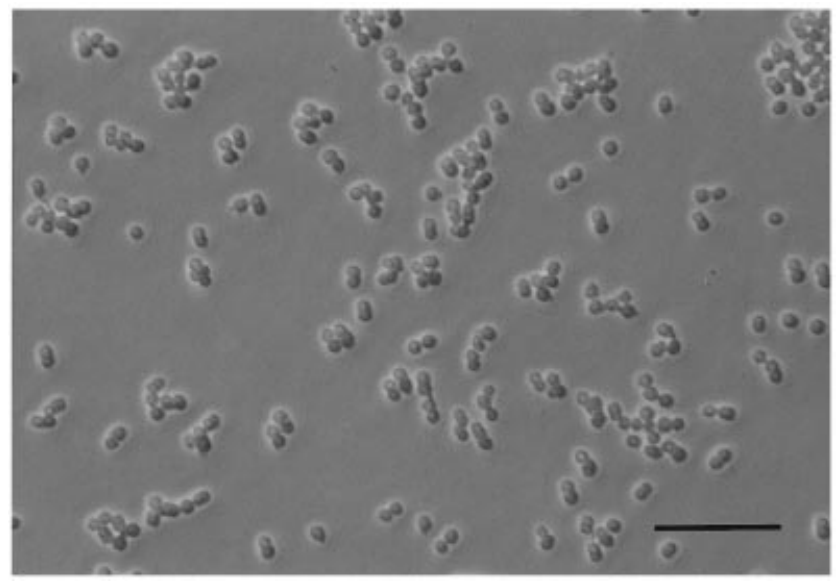

Fig. 1. Phase-contrast photomicrograph of strain $\operatorname{Lg} 2^{\top}$ cells aerobically grown in NM-1 medium at $30^{\circ} \mathrm{C}$. Bar, $10 \mu \mathrm{m}$.

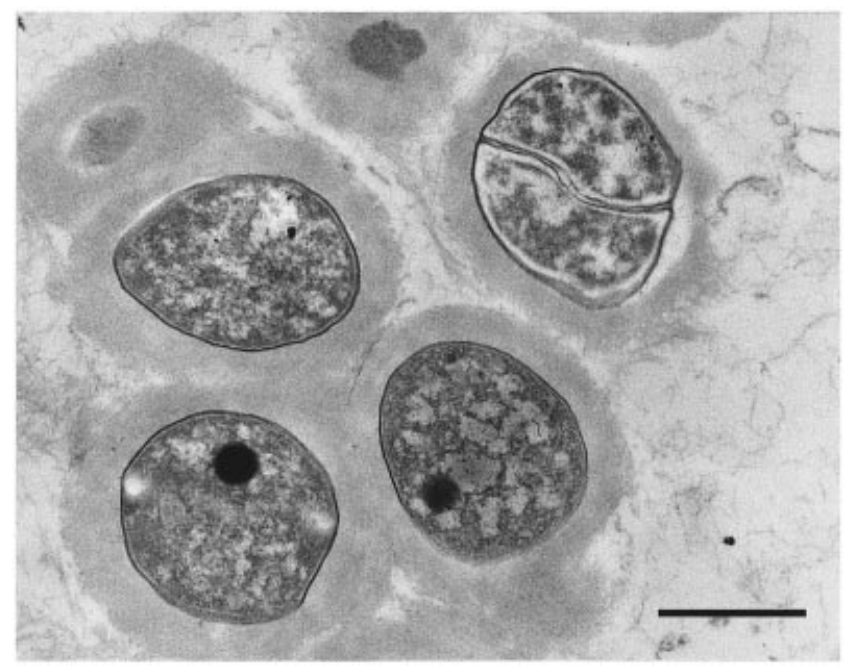

Fig. 2. Transmission electron micrograph of strain $\operatorname{Lg}^{\top}$ cells showing capsules outside the cells. Cells were grown in NM-1 medium at $30^{\circ} \mathrm{C}$ under aerobic conditions. Bar, $1 \mu \mathrm{m}$.

significantly in the exponential phase, and gradually decreased in the stationary phase. The highest cellular glycogen content that we have ever detected was $8.4 \%$ based on dry cell weight.

\section{Physiological and biochemical characteristics}

Strain $\mathrm{Lg} 2^{\mathrm{T}}$ could utilize arabinose, cellobiose, galactose, glucose, lactose, maltose, mannose, melibiose, saccharose, xylose, inositol, mannitol, acetate, propionate, pyruvate, succinate, alanine, arginine and histidine as carbon sources (all tests were performed at $30{ }^{\circ} \mathrm{C}$ under aerobic conditions). The isolate could also hydrolyse starch and glycogen. However, the isolate did not utilize trehalose, dulcitol, ethanol, glycerol, methanol, propanol, malate, asparagine, glutamate and glutamine as growth substrates.

Table 1 summarizes the major biochemical characteristics of strain $\operatorname{Lg} 2^{\mathrm{T}}$. Catalase and oxidase activities of strain $\operatorname{Lg} 2^{\mathrm{T}}$ were found to be positive. Strain $\mathrm{Lg} 2^{\mathrm{T}}$ could utilize nitrate as an electron acceptor, but could not further reduce nitrite to nitrogen gas under anaerobic conditions. The isolate was judged to exhibit no orthophosphate uptake activity or accumulation of intracellular polyphosphate, because no cells were stained positive with Neisser staining.

\section{Chemotaxonomic characteristics}

The GC of methylated cellular fatty acid analysis indicates that strain $\mathrm{Lg}^{\mathrm{T}}$ contained anteiso- $\mathrm{C}_{15: 0}$ $(37 \cdot 1 \%)$, iso- $\mathrm{C}_{14: 0} \quad(14 \cdot 1 \%), \mathrm{C}_{16: 0} \quad(12.9 \%)$ and iso- $\mathrm{C}_{16: 0}(10 \cdot 8 \%)$. In addition, substantial amounts of $\mathrm{C}_{15: 0}(5.9 \%), \mathrm{C}_{18: 0}(4.6 \%), \mathrm{C}_{14: 0}(3.7 \%)$ and iso- $\mathrm{C}_{15: 0}(2 \cdot 2 \%)$ were also detected. Analysis of the DAP isomer by TLC revealed that meso-DAP was 


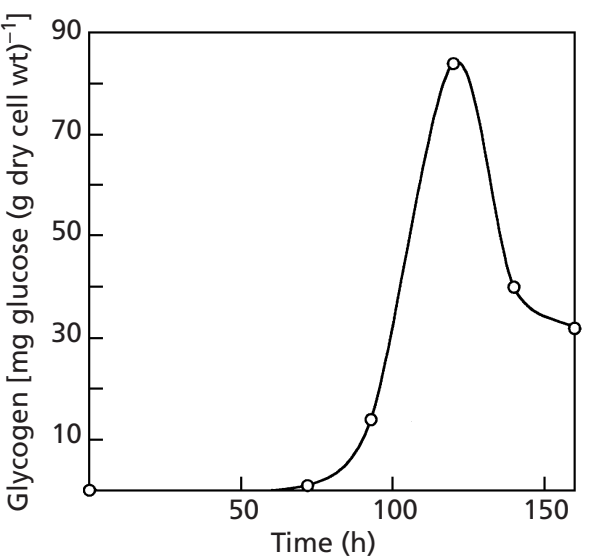

Fig. 3. Profile of glycogen uptake by strain $\operatorname{Lg} 2^{\top}$ under aerobic conditions. Cells were grown in NM-1 medium. Glycogen was extracted from dry cells. After extraction and hydrolysis, the amount of glucose was determined by enzyme assay.

contained in the cell wall peptidoglycan of the isolate. The dominant respiratory quinone of strain $\mathrm{Lg}^{\mathrm{T}}$ was menaquinone- $9\left(\mathrm{H}_{4}\right)$. The $\mathrm{G}+\mathrm{C}$ content of the genomic DNA of strain $\mathrm{Lg} 2^{\mathrm{T}}$ was $70.5 \mathrm{~mol} \%$.

\section{Phylogenetic analysis based on the 16S rRNA gene sequence}

Almost the full length sequence $(1438 \mathrm{bp})$ of the $16 \mathrm{~S}$ rRNA gene of strain $\mathrm{Lg} 2^{\mathrm{T}}$ was determined. A phylogenetic tree (Fig. 4) was constructed by the neighbour- joining method (Kimura, 1980; Saitou \& Nei, 1987). The sequence of $B$. subtilis, which belongs to the low $\mathrm{G}+\mathrm{C}$ Gram-positive bacteria, was used to root the tree. Strain $\mathrm{Lg}^{\mathrm{T}}$ formed a cluster with the genera Microlunatus, Friedmanniella, Nocardioides and Aeromicrobium in the high $\mathrm{G}+\mathrm{C}$ group of Gram-positive bacteria. The isolate was closely related to Microlunatus phosphovorus (93\% sequence similarity) and $F$. antarctica $(92 \%)$.

\section{DISCUSSION}

In the past few decades, the microbiological aspect of EBPR or activated sludge processes has been extensively studied to improve the process operation (Bond et al., 1995; Cloete et al., 1985; Cloete \& Steyn, 1987;Nakamura et al., 1991; Streichen et al., 1990; Suresh et al., 1985; Wagner et al., 1993, 1994; Yoshimi et al., 1996). One approach to understanding the biochemical mechanism was the isolation of representative bacteria enriched in the process. In our previous studies, we successfully isolated two bacterial strains with unique chemotaxonomic and metabolic characteristics: these included a polyphosphate-accumulating bacterium, Microlunatus phosphovorus (Nakamura et al., 1995b), and a polysaccharide-accumulating bacterium, Microsphaera multipartita (Yoshimi et al., 1996). Here, we have extended our study to a Grampositive, non-spore-forming, and non-motile coccus, strain $\operatorname{Lg} 2^{\mathrm{T}}$, which was isolated from a reactor with good biological phosphorus removal activity (Liu et al., 1997). Interestingly, this strain was not able to accumulate intracellular polyphosphate or take up

Table 1. Phenotypic characteristics of strain $\mathrm{Lg}^{\top}$ and related species in the high $\mathrm{G}+\mathrm{C}$ content Gram-positive group

Data were taken from the following references: Microlunatus phosphovorus, Nakamura et al. (1995b); F. antarctica, Schumann et al. (1997). +, Positive; - , negative.

\begin{tabular}{|c|c|c|c|}
\hline Characteristic & $\mathbf{L g}^{\mathrm{T}}$ & $\begin{array}{l}\text { Microlunatus } \\
\text { phosphovorus }\end{array}$ & $\begin{array}{l}\text { Friedmanniella } \\
\quad \text { antarctica }\end{array}$ \\
\hline Cell shape & $\begin{array}{c}\text { Cocci (single, pair or } \\
\text { packet) }\end{array}$ & Cocci (single or pair) & Cocci \\
\hline Cell size (diameter) & $0 \cdot 5-2 \cdot 2 \mu \mathrm{m}$ & $0 \cdot 8-2 \cdot 0 \mu \mathrm{m}$ & $1 \cdot 8-2 \cdot 5 \mu \mathrm{m}$ \\
\hline Gram staining & + & + & + \\
\hline Motility & - & - & - \\
\hline Spore formation & - & - & - \\
\hline Colour of colony & White & Cream & Orange \\
\hline Polyphosphate granules & - & + & - \\
\hline Oxidase & + & + & - \\
\hline Catalase & + & + & + \\
\hline Nitrate reduction & + & + & - \\
\hline Denitrification & - & - & - \\
\hline Acid production from glucose & + & + & - \\
\hline DNA G $+C$ content & $70 \cdot 5 \mathrm{~mol} \%$ & $67.9 \mathrm{~mol} \%$ & $73.0 \mathrm{~mol} \%$ \\
\hline Major quinone & Menaquinone-9 $\left(\mathrm{H}_{4}\right)$ & Menaquinone-9( $\left.\mathrm{H}_{4}\right)$ & Menaquinone-9( $\left.\mathrm{H}_{4}\right)$ \\
\hline Cellular fatty acids & $\begin{array}{c}\text { iso- } \mathrm{C}_{14: 0} \text {, anteiso- } \mathrm{C}_{15: 0}, \\
\mathrm{C}_{16: 0}\end{array}$ & $\begin{array}{c}\text { anteiso- } \mathrm{C}_{15: 0}, \text { iso- } \mathrm{C}_{15: 0}, \\
\mathrm{C}_{16: 0}\end{array}$ & anteiso- $\mathrm{C}_{15: 0}$, iso- $\mathrm{C}_{15: 0}$ \\
\hline Peptidoglycan & meso-DAP & LL-DAP & LL-DAP \\
\hline
\end{tabular}




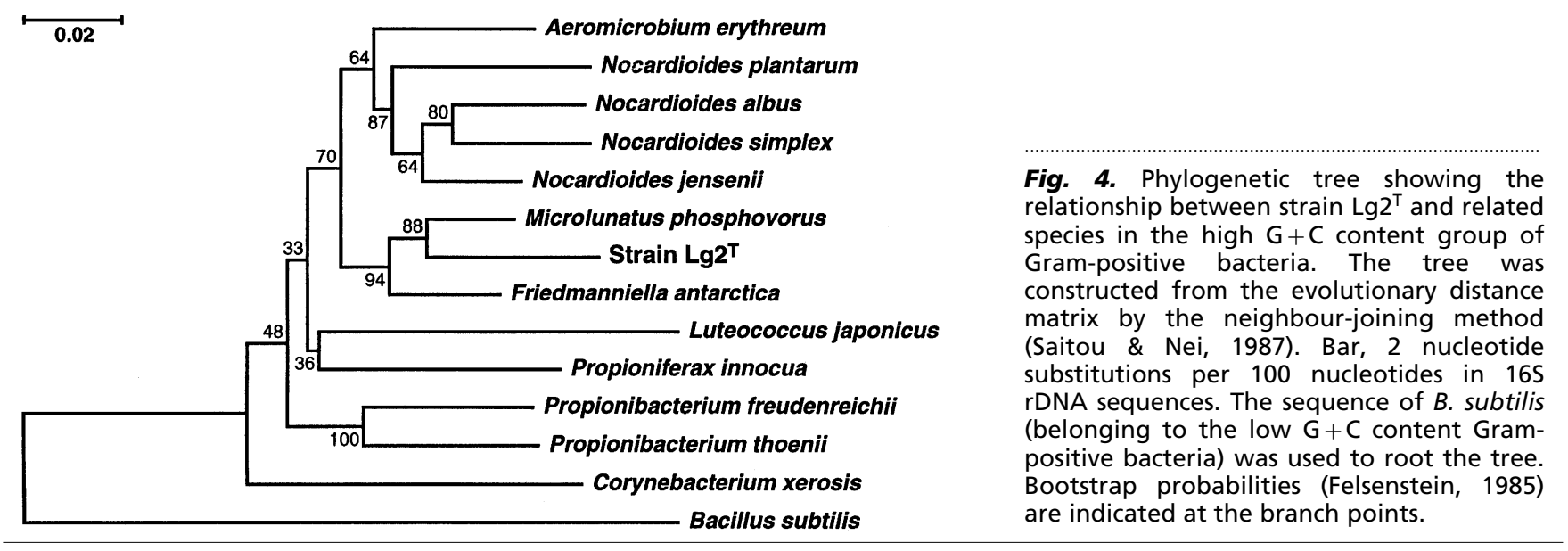

orthophosphate under either anaerobic or aerobic conditions. Instead, like Microsphaera multipartita, it could accumulate a large amount of carbon substrates as cellular glycogen.

A phylogenetic analysis based on the 16S rRNA gene sequence revealed that strain $\mathrm{Lg} 2^{\mathrm{T}}$ is associated with the high $\mathrm{G}+\mathrm{C}$ content group of the Gram-positive bacteria. It was closely related to Microlunatus phosphovorus (Nakamura et al., 1995a) and F. antarctica (Schumann et al., 1997). The phenotypic characteristics summarized in Table 1 further indicate that strain $\mathrm{Lg} 2^{\mathrm{T}}$, Microlunatus phosphovorus and F. antarctica share several common features. They are all non-spore-forming, non-motile cocci, contain anteiso$\mathrm{C}_{15: 0}$ as the major fatty acid component, contain menaquinone- $9\left(\mathrm{H}_{4}\right)$ as the major quinone, are catalase-positive, and do not possess denitrification capability. However, the similarities of the 16S rRNA gene sequence between the isolate and these two authentic species were $92-93 \%$, which are low enough to place the isolate in a new and distinct taxon.

Strain $\mathrm{Lg} 2^{\mathrm{T}}$ was also distinguishable from both Microlunatus phosphovorus and $F$. antarctica in the following phenotypic aspects: (1) the isolate contains meso-DAP in the cell wall peptidoglycan, while the two relatives have a different peptidoglycan type (LL-DAP); (2) iso$\mathrm{C}_{14: 0}$ is one of the major fatty acid components in the isolate $(14 \cdot 1 \%$ of total fatty acids), while it is detected in the other relatives as a trace amount $(<4 \%)$; (3) strain $\mathrm{Lg} 2^{\mathrm{T}}$ has a genomic $\mathrm{G}+\mathrm{C}$ content of $70 \cdot 6$ $\mathrm{mol} \%$, and this value is different from those of Microlunatus phosphovorus $(67.9 \%)$ and $F$. antarctica $(73 \%)$; (4) the isolate produces no pigment and its colonies are white, while colonies of the other two are cream or orange.

Furthermore, the substrate utilization profiles of strain $\mathrm{Lg} 2^{\mathrm{T}}$ and the two related species were different. Microlunatus phosphovorus can utilize trehalose, dulcitol, asparagine, glutamate and glutamine, while strain $\mathrm{Lg} 2^{\mathrm{T}}$ can not. On the other hand, strain $\mathrm{Lg} 2^{\mathrm{T}}$ can utilize lactose, glycogen, propionate and succinate, while Microlunatus phosphovorus can not (Nakamura et al., 1995b). In contrast with strain $\mathrm{Lg}^{\mathrm{T}}$ and Microlunatus phosphovorus, which can use a wide range of organic compounds as energy sources, $F$. antarctica has a very limited carbon utilization ability (Schumann et al., 1997).

In addition, $F$. antarctica was rather psychrophilic (the optimum growth temperature is $22^{\circ} \mathrm{C}$ ), whereas the isolate is a mesophilic bacterium with the optimum at $30{ }^{\circ} \mathrm{C}$. Microlunatus phosphovorus can accumulate cellular polyphosphate, and can take up and store several different sugars as polyglucose under both anaerobic and aerobic conditions (Nakamura et al., $1995 \mathrm{a}, \mathrm{b})$. Strain $\mathrm{Lg}^{\mathrm{T}}$ can store substrates as intracellular glycogen but can not accumulate polyphosphate.

On the basis of the results of the phenotypic and genotypic comparisons, we propose that a new genus and species, Micropruina glycogenica gen. nov., sp. nov., should be established for strain $\operatorname{Lg} 2^{\mathrm{T}}$ described in this study.

\section{Description of Micropruina gen. nov.}

Micropruina (Mi.cro.prui'na. Gr. adj. micros small, fine; M. L. fem. n. pruina hoarfrost; M. L. fem. n. Micropruina fine hoarfrost).

Cells are Gram-positive, non-motile, cocci (diameter $0 \cdot 5-2 \cdot 2 \mu \mathrm{m})$, and usually occur in pairs, packets or clusters. Spore formation is not observed. Capsules are formed. Colonies and liquid cultures are white in colour. Neisser stain is negative. An aerobic chemoorganotroph. Catalase and oxidase are produced. The cell wall peptidoglycan contains meso-DAP. The major cellular fatty acids are iso- $\mathrm{C}_{14: 0}$, anteiso- $\mathrm{C}_{15: 0}, \mathrm{C}_{16: 0}$ and iso- $\mathrm{C}_{16: 0}$. The cells contain menaquinone- $9\left(\mathrm{H}_{4}\right)$ as the major quinone. The phylogenetic position is in the high $\mathrm{G}+\mathrm{C}$ Gram-positive bacteria; the genera Microlunatus and Friedmanniella are closely related to this genus. The $\mathrm{G}+\mathrm{C}$ content of the genomic DNA is $70 \cdot 5$ mol \%. The type species is Micropruina glycogenica. 


\section{Description of Micropruina glycogenica sp. nov.}

Micropruina glycogenica (gly.co.gen.i'ca. Gr. suff. -icus related to, belonging to; N. L. adj. glycogenica referring to the ability to accumulate glycogen).

The morphology and chemotaxonomic features of the species are the same as those described above for the genus.

The species can store substrates as intracellular glycogen. Growth occurs at $20-35^{\circ} \mathrm{C}$ and at $\mathrm{pH}$ 6-8. The optimal growth temperature and $\mathrm{pH}$ are $30^{\circ} \mathrm{C}$ and $7 \cdot 0$, respectively. A slow growing organism. The species tolerates up to $3.0 \% \mathrm{NaCl}$ in the medium. Cells reduce nitrate to nitrite under anaerobic conditions, but do not reduce nitrite to nitrogen. Cells grow on glucose, mannose, galactose, xylose, arabinose, sucrose, maltose, lactose, cellobiose and melibiose, but not trehalose. Starch and glycogen are utilized. Cells utilize sugar alcohols, including inositol and mannitol, but not dulcitol. Acetate, propionate, pyruvate and succinate are utilized, but not malate. On the basis of the phylogenetic comparison of $16 \mathrm{~S}$ rRNA sequences, the bacterium belongs to the high $\mathrm{G}+\mathrm{C}$ Gram-positive bacteria. The closest relative is Microlunatus phosphovorus ( $93 \%$ sequence similarity). The $\mathrm{G}+\mathrm{C}$ content of the genomic DNA is $70.5 \mathrm{~mol} \%$. The type strain is $\mathrm{Lg} 2^{\mathrm{T}}$, which has been deposited in the Japan Collection of Microorganisms (RIKEN) as JCM 10248 ${ }^{\mathrm{T}}$.

\section{ACKNOWLEDGEMENTS}

We thank the following researchers in the National Institute of Bioscience and Human-Technology: Aiko Sukegawa for cultivation and 16S rDNA sequencing; Xian Ying-Meng for transmission electron microscopy; Toshihiko Suzuki and Yasuyo Ashizawa for isoprenoid quinone analysis. We also thank Yoshikuni Urushigawa (National Institute for Resources and Environment, Agency of Industrial Science and Technology) for his useful advice concerning fatty acid analysis.

\section{REFERENCES}

Beacham, A. M., Seviour, R. J. \& Lindrea, K. C. (1992). Polyphosphate accumulating abilities of Acinetobacter isolates from a biological nutrient removal pilot plant. Water Res 26, 121-122.

Bond, P. L., Hugenholtz, P., Keller, J. \& Blackall, L. L. (1995). Bacterial community structures of phosphate-removing and non-phosphate-removing activated sludge from sequencing batch reactors. Appl Environ Microbiol 61, 1910-1916.

Cloete, T. E. \& Steyn, P. L. (1987). A combined fluorescent antibody-membrane filter technique for enumerating Acinetobacter in activated sludge. In Advances in Water Pollution Control, Biological Phosphate Removal from Wastewaters, pp. 335-338. Edited by R. Ramadori. Oxford: Pergamon Press.

Cloete, T. E., Steyn, P. L. \& Buchan, L. (1985). An auto-ecological study of Acinetobacter in activated sludge. Environ Technol Lett 5, 457-463.

Deinema, M. H., Habets, L. H. A., Scholten, J., Turkstra, E. \& Webers, H. A. A. M. (1980). The accumulation of polyphosphate in Acinetobacter spp. FEMS Microbiol Lett 9, 275-279.
Elson, L. A. \& Morgan, W. T. (1993). A colorimetric method for the determination of glucosamine and chondrosamine. Biochem $J$ 27, 1824-1828.

Felsenstein, J. (1985). Confidence limits of phylogenies: an approach using the bootstrap. Evolution 39, 783-791.

Fuhs, G. W. \& Chen, M. (1975). Microbiological basis of phosphate removal in the activated sludge process for the treatment of wastewater. Microb Ecol 2, 119-138.

Groenestijn, J. W., Zuidema, M., van de Worp, J. J. M., Deinema, M. H. \& Zehnder, A. J. B. (1989). Influence of environmental parameters on polyphosphate accumulation in Acinetobacter sp. Antonie Leeuwenhoek 55, 67-82.

Hiraishi, A. (1992). Direct automated sequencing of $16 \mathrm{~S}$ rDNA amplified by polymerase chain reaction from bacterial cultures without DNA purification. Lett Appl Microbiol 15, 210-213.

Hiraishi, A., Shin, Y. K., Ueda, Y. \& Sugiyama, J. (1994). Automated sequencing of PCR-amplified 16S rDNA on 'Hydrolink' gels. J Microbiol Methods 19, 145-154.

Jenkins, D., Richard, M. G. \& Daigger, G. L. (1993). Manual on the Causes and Control of Activated Sludge Bulking and Foaming, 2nd edn. Boca Raton, FL: Lewis Publishers.

Kamagata, Y. \& Mikami, E. (1991). Isolation and characterization of a novel thermophilic Methanosaeta strain. Int J Syst Bacteriol 41, 191-196.

Kimura, M. (1980). A simple method for estimating evolutionary rates of base substitution through comparative studies of nucleotide sequences. J Mol Evol 16, 111-120.

Komagata, K. \& Suzuki, K. (1987). Lipid and cell-wall analysis in bacterial systematics. Methods Microbiol 19, 161-207.

Kumar, S., Tamura, K. \& Nei, M. (1993). MEGA: molecular evolutionary genetics analysis, version 1.0. University Park: The Pennsylvania State University.

Kushida, H. (1980). An improved embedding method using ERL 4206 and Quetol 653. J Electron Microsc 29, 193-194.

Liu, W.-T. (1995). Function, dynamics, and diversity of microbial population in anaerobic-aerobic activated sludge process for biological phosphorus removal. Doctoral thesis, University of Tokyo.

Liu, W.-T., Nakamura, K., Matsuo, T. \& Mino, T. (1997). Internal energy-based competition between polyphosphate- and glycogen-accumulating bacteria in biological phosphorus removal reactor - effect of the $\mathrm{P} / \mathrm{C}$ feeding ratio. Water Res $\mathbf{3 1}$, $1430-1438$

Lott, J. A. \& Turner, K. (1975). Evaluation of Trinder's glucose oxidase method for measuring glucose in serum and urine. Clin Chem 21, 1754-1760.

Lötter, L. H. \& Pitman, A. P. (1992). Improved biological phosphorus removal resulting from the enrichment of reactor feeded with fermentation products. Water Sci Technol 26, 943-953.

Magee, C. M., Rodeheaver, G. \& Edgerton, R. F. (1975). A more reliable gram staining technique for diagnosis of surgical infections. Am J Surg 130, 341-346.

Nakamura, K., Masuda, K. \& Mikami, E. (1991). Isolation of a new type of polyphosphate accumulating bacterium and its phosphate removal characteristics. J Ferment Technol 4, 258-263.

Nakamura, K., Ishikawa, A. \& Kawaharasaki, M. (1995a). Phosphate uptake and release activity in immobilized polyphosphate-accumulating bacterium Microlunatus phosphovorus strain NM-1. J Ferment Bioeng 80, 377-382.

Nakamura, K., Hiraishi, A., Yoshimi, Y., Kawaharasaki, M., Masuda, K. \& Kamagata, Y. (1995b). Microlunatus phosphovorus 
gen. nov., sp. nov., a new gram-positive polyphosphateaccumulating bacterium isolated from activated sludge. Int $J$ Syst Bacteriol 45, 17-22.

Ohtake, H., Takahashi, K., Tsuzuki, Y. \& Toda, K. (1985). Uptake and release of phosphate by a pure culture of Acinetobacter calcoaceticus. Water Res 19, 1587-1594.

Pitcher, D. G. \& Collins, M. D. (1991). Phylogenetic analysis of some LL-diaminopimelic acid-containing coryneform bacteria from human skin: description of Propionibacterium innocuum sp. nov. FEMS Microbiol Lett 68, 295-300.

Saitou, N. \& Nei, M. (1987). The neighbor joining method: a new method for reconstructing phylogenetic trees. Mol Biol Evol 4, 406-425.

Schumann, P., Prauser, H., Rainey, F. A., Stackebrandt, E. \& Hirsch, P. (1997). Friedmanniella antarctica gen. nov., sp. nov., an LL-diaminopimelic acid-containing actinomycete from antarctic sandstone. Int J Syst Bacteriol 47, 278-283.

Shoda, M., Ohsumi, T. \& Udaka, S. (1980). Screening for high phosphate accumulating bacteria. Agric Biol Chem 44, 319-324.

Smibert, R. M. \& Krieg, N. R. (1981). General characterization. In Manual of Methods for General Bacteriology, pp. 409-443. Edited by P. Gerhardt, R. G. E. Murray, R. N. Costilow, E. W. Nester, W. A. Wood, N. R. Krieg \& G. B. Phillips. Washington, DC: American Society for Microbiology.

Stante, L., Cellamare, C. M., Malaspina, F., Bortone, G. \& Tilche, A. (1997). Biological phosphorus removal by pure culture of Lampropedia spp. Water Res 31, 1317-1324.

Streichen, M., Golecki, J. R. \& Schön, G. (1990). Polyphosphate- accumulating bacteria from different processes for biological phosphorus removal. FEMS Microb Ecol 73, 113-129.

Suresh, N., Warburg, R., Timmerman, M., Wells, J., Coccia, M., Roberts, M. F. \& Halvorson, H. O. (1985). New strategies for the isolation of microorganisms responsible for phosphate accumulation. Water Sci Technol 17, 43-56.

Tamaoka, J., Katayama-Fujimura, Y. \& Kuraishi, H. (1983). Analysis of bacterial menaquinone mixtures by high performance liquid chromatography. J Appl Bacteriol 54, 31-36.

Thompson, J. D., Higgins, D. G. \& Gibson, T. J. (1994). CLUSTAL $\mathrm{W}$ : improving the sensitivity of progressive multiple sequence alignment through sequence weighting, position-specific gap penalties and weight matrix choice. Nucleic Acids Res 22, 4673-4680.

Wagner, M., Amann, R., Lemmer, H. \& Schleifer, K.-H. (1993). Probing activated sludge with oligonucleotides specific for Proteobacteria: inadequacy of culture-dependent methods for describing microbial community structure. Appl Environ Microbiol 59, 1520-1525.

Wagner, M., Erhart, R., Manz, W., Amann, R., Lemmer, H., Wedi, D. \& Schleifer, K.-H. (1994). Development of an rRNA-targeted oligonucleotide probe specific for the genus Acinetobacter and its application for in situ monitoring in activated sludge. Appl Environ Microbiol 60, 792-800.

Yoshimi, Y., Hiraishi, A. \& Nakamura, K. (1996). Isolation and characterization of Microsphaera multipartita gen. nov., sp. nov., a polysaccharide-accumulating gram-positive bacterium from activated sludge. Int J Syst Bacteriol 46, 519-525. 